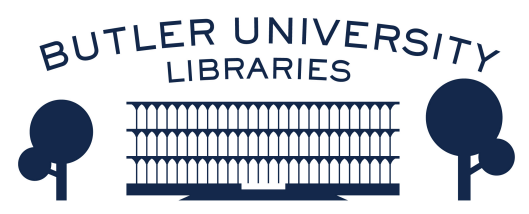

Journal of Hindu-Christian Studies

Volume 28

Article 6

2015

\title{
Hindu-Christian Relations in the Everyday Life of North Indian Pentecostals
}

Julia Kuhlin

Uppsala University

Follow this and additional works at: https://digitalcommons.butler.edu/jhcs

\section{Recommended Citation}

Kuhlin, Julia (2015) "Hindu-Christian Relations in the Everyday Life of North Indian Pentecostals," Journal of Hindu-Christian Studies: Vol. 28, Article 6.

Available at: https://doi.org/10.7825/2164-6279.1605

The Journal of Hindu-Christian Studies is a publication of the Society for Hindu-Christian Studies. The digital version is made available by Digital Commons @ Butler University. For questions about the Journal or the Society, please contact cbauman@butler.edu. For more information about Digital Commons @ Butler University, please contact digitalscholarship@butler.edu. 


\title{
Hindu-Christian Relations in the Everyday Life of North Indian Pentecostals
}

\author{
Julia Kuhlin \\ Uppsala University
}

OVER the last few decades, Hindu-Christian relations in India appear to have taken a new worrying turn. Since 1998 violent attacks against Christians in India have increased significantly, and there are no signs of decline. Pentecostal and Pentecostal-like groups have been afflicted to a greater extent by this recent development and are disproportionately targeted in attacks in comparison to other Christians. ${ }^{1}$ Considering the explosion of academic studies on Pentecostalism worldwide, it is striking that so little attention has been paid to the contemporary situation of Indian Pentecostals. In particular, there is a notable lack of studies dealing with Indian Pentecostals' everyday life from a non-church perspective. The aim of this case study-consisting of indepth interviews with students at the Pentecostal college Doon Bible College ${ }^{2}$ in Dehradun (Uttarakhand)-is to explore from a micro perspective how North Indian Pentecostals perceive and experience the relationship with the Hindu surroundings in their everyday life. The study proceeds from a Social Identity Theory (SIT) framework, accordingly paying particular attention to the construction and perception of group relations.

A central finding of the study is that the informants did not perceive Hindu-Christian relations as a matter of "we and them" but described both groups as internally differentiated. This understanding of the Christian in-group and the Hindu out-group meant that Hindu-Christian relations, for the informants, did not simply involve two religious groups relating to each other, but consisted of various Christian and Hindu subgroups with complicated interrelationships. Furthermore, the Christian in-group and the Hindu out-group were overlapped by various identities and relations, such as caste identity, the village community and families. The dualistic worldview which is often associated with Pentecostals did not conform to either the

Julia Kuhlin is a PhD candidate in World Christianity and Interreligious Studies at the Faculty of Theology at Uppsala University, Sweden. Kuhlin's major research interests are focused around questions concerning the Pentecostal movement in India and Hindu-Christian relations. Her PhD project concerns lived religion among Indian Pentecostal women in New Delhi. The present article is a condensed version of her Master's thesis Love Thy Hindu Neighbor as Thyself (2014) and deals with North Indian Pentecostals' everyday interaction with the Hindu population and experiences of HinduChristian relations.

Journal of Hindu-Christian Studies 28 (2015):40-54 
informants' perception of Hindu-Christian relations or their everyday interaction patterns. All informants had Hindu family members or close Hindu friends with whom they frequently interacted. In addition, as a result of the arrangement of village life, the informants coming from rural areas intermingled to a great extent with members of the Hindu out-group who were neither family nor friends. Hindu-Christians relations were described as mostly trouble-free on micro and meso-levels; conflicts were perceived as exceptions to a normal peaceful coexistence. However, the informants expressed fear and anxiety concerning Hindu-Christian relations on the national level.

\section{Pentecostalism in India}

The origin of the Pentecostal movement in India is a much-disputed topic. The discussion generally concerns whether Indian Pentecostalism is to be regarded as an American import arriving in the early $20^{\text {th }}$ century or an indigenous Indian spiritual movement. Scholars of the latter position argue that Pentecostal-like revivals ${ }^{3}$ have taken place within India since the late $19^{\text {th }}$ century, and even though American missionaries played a crucial role in linking the various revivals and groups into a movement, the foundation for the movement had already been laid by the time of their arrival. ${ }^{4}$ However, the Mukti revival in Maharashtra, led by Pandita Ramabai, and the events in Khasi Hills (in present-day Assam) are usually regarded by researchers of both positions as having been vital for the establishment and spread of the Pentecostal movement in India. With the arrival of missionaries from Azusa Street the ideas and experiences that came out of the revivals were given a significant boost, and a Pentecostal network began to be established. ${ }^{5}$ The question of origin has become a burning issue within Indian Pentecostalism due to the commonlyheld opinion among Hindu nationalistic groups that Christianity is a foreign import. As a consequence, the rather Eurocentric description of the Pentecostal movement's history in India (which tends to place a great deal of emphasis on the efforts of foreign missionaries) is being revised, and attention is called to the role played by indigenous adherents of the movement.

While the Pentecostal movement worldwide experienced a considerable growth during the first part of the $20^{\text {th }}$ century, it had a comparatively slow beginning in India. ${ }^{6}$ Even though churches and Bible schools had been founded around the country, the movement had difficulties in reaching out to a larger public. After independence in 1947 the movement got an upswing as the Charismatic wave found its way into the Catholic Church and mainline Protestant denominations. At the same time increasing numbers of independent Pentecostal churches started to emerge, and the growth of Pentecostal and Charismatic Christianity accelerated dramatically. With the appearance of a wide range of independent Pentecostal churches a space was opened up for lower caste Pentecostal leaders, which has been an important factor in the movement's success, yet has also contributed to its vulnerable position. $^{7}$

A main characteristic of the Pentecostal movement globally, including India, is its emphasis on mission. Initially, there was a strong belief that the end times were rapidly approaching and, as a consequence, there was an urge to save as many souls as possible. Even 
though the belief in an encroaching end times has, to some extent, been toned down in India, Pentecostal groups nonetheless tend to put strong emphasis on the importance of spreading the gospel. ${ }^{8}$ However, methods of evangelism have changed over time, and nowadays many Indian churches have started to shift their focus from evangelistic work to social work. Pentecostals are often accused of using aggressive methods of evangelization, but recent research indicates that this is not a uniform tendency within the contemporary Indian Pentecost movement, but limited to parts of the movement. ${ }^{9}$

Evangelism and conversion have been major sources of conflict and disagreement within Hindu-Christian relations throughout $20^{\text {th }}$ century. Sebastian Kim has neatly traced this debate in his book In Search for Identity. ${ }^{10}$ Among other things, Kim ${ }^{11}$ describes the discussions preceding the formation of the Indian Constitution in which the question of conversion and proselytization was much in focus. Even though the right to proselytize was inscribed in the Constitution, the issue over conversion was never resolved and has continued to be an ongoing conflict within Hindu-Christian relations. It is often argued that Pentecostals are disproportionally targeted in attacks due to their focus on mission. However, in the newly published book Pentecostals, Proselytization, and Anti-Christian Violence in Contemporary India, Bauman ${ }^{12}$ suggests that this factor is just part of a much more complicated situation. Bauman brings complexity to the matter by, for example, highlighting the vulnerable situation of Pentecostal churches, which are often situated in traditional Hindu-dominated areas, contain high numbers of women and Dalits, and do not have the protective network of a strong denomination that other churches may have. ${ }^{13}$ He also highlights Pentecostals' strong engagement in the areas of healing and exorcism, which makes them competitors with other religious groups.

An emphasis on signs and wonders is another major characteristic among Indian Pentecostals. In meetings, the experiences of the Holy Spirit, spontaneity and emotionalism are often given prominence. There is typically a strong belief that any Christian (lay or ordained) can be empowered by the Holy Spirit and be given "spiritual gifts," such as the ability to "speak in tongues," perform healing, caste out demons and prophesize. In his work on south Indian Pentecostalism Michael Bergunder $^{14}$ describes that healing and exorcism provide an overlapping set of practices between Pentecostals and Hindu popular spirituality that leads to contact between the two groups. Instead of rejecting commonly-held Hindu popular beliefs that spirits affect daily life, Pentecostal churches tend to embrace these and offer their own solutions on how to deal with them. Bauman draws a similar conclusion and, furthermore, argues that the emphasis on healing is a major explanation for the Pentecostal movement's growth in India. ${ }^{15}$

The Pentecostal tendency to embrace other spiritual worldviews is, however, often twosided. Even if Pentecostals tend to embrace the ontological claims of the existence of a spiritual realm, they seldom accept the beliefs that accompany them. Other religions are often demonized and a sharp division is made between Christians and non-Christians. ${ }^{16}$ To be a Pentecostal often involves following a rigid moral code derived from a rather literalist 
reading of the Bible. According to Bergunder, the discussion over ethical norms is an incendiary topic among Indian Pentecostals, generating conflicts among pastors as well as laity. In terms of the discourse about Hinduism, findings of recent research indicate that the tendency to demonize other religions has lessened somewhat in recent years. Anita Suneson ${ }^{17}$ found that the Pentecostals she interviewed in two churches in Bangalore tried to speak diplomatically regarding Hinduism and Hindus in order to avoid causing offense. Similarly, the pastors Lukose $^{18}$ interviewed stated that their former perception of nonChristians as being "destined to hell" has been replaced by a more positive attitude, e.g. as "future believers" and "pre-Christian neighbors."

This brief background of Indian Pentecostalism has hopefully shown that it is a vibrant movement undergoing continual changes. Although this introduction has mainly focused on what distinguishes the movement as a whole, it should be underlined that Pentecostal churches diverge to a high degree. The focus on practice and experience rather than on a formulated theology, as well as the lack of a unifying denominational structure means that churches are often highly influenced by local contexts.

\section{Method}

This case study includes nine informants from North India, ${ }^{19}$ who, at the time of the interviews, were studying at the Pentecostal college Doon Bible College in Dehradun, Uttarakhand. The purpose of the study is not to provide conclusions that could be generalizable for Indian Pentecostals as a whole, but rather to bring to light and discuss Hindu-Christian relations in the context of the everyday life of Pentecostals. The primary material was gathered using semi-structured in-depth interviews. Each informant was interviewed twice during a period of two weeks in January 2014. The interviews were subsequently fully transcribed, coded and analyzed following Jens Rennstram \& David Waterford's ${ }^{20}$ mode of procedure for analyzing qualitative material.

I aimed at reaching maximum diversity and variation among the informants in terms of religious background (converted/nonconverted), gender and rural/urban background in order to be able to compare how such variables could influence experiences and understanding of Hindu-Christian relations. The informants have been given code names, and certain sensitive information has been excluded in order to maintain anonymity.

The informants consist of seven men and two women. All informants are between the ages of 20-30 years. Three grew up in a Christian family, and the other six had, individually or together with their family, converted from Hinduism. Out of the nine informants, four grew up in a rural setting. The informants originate from six different states and one union territory: Chhattisgarh, Uttarakhand, Uttar Pradesh, Bihar, West Bengal, and Delhi.

The choice to interview students at a Pentecostal college means that this study does not represent the average Indian Pentecostal. Moreover, the informants were persons with the opportunity, qualifications and most often with an interest in studying theology. The factor that all informants were between the ages of 20 and 30 may also have influenced the result, as interaction patterns, experiences of Hindu-Christian relations and attitudes 
44 Julia Kuhlin

regarding the Hindu out-group may differ between age-groups.

\section{Theoretical Framework}

The present study adheres to the approach of social identity theory (SIT) originating in the academic works of Henri Tajfel (1919-1982), and fully formulated in cooperation with John Turner in the mid- to late-70s. ${ }^{21}$ The reason for the choice of this particular approach to social identity in the present study is because of its strong emphasis on intergroup relations.

Social identity concerns the individual's identification with a social group, and his/her social categorization of people in their surroundings. ${ }^{22}$ Tajfel has defined social identity as "that part of an individual's selfconcept which derives from his knowledge of his membership in a social group (or groups) together with the value and emotional significance attached to that membership." ${ }^{23}$ A social group that an individual identifies with is termed in-group, while social groups the individual does not identify with are called outgroups.

SIT was originally developed and inspired from a series of laboratory experiments. In the experiments Tajfel et al. used simple social categorization (e.g. eye color) as a means to investigate the influence of social belonging on group behavior and formation of attitudes. This form of experimental method grew to be termed the "minimal group paradigm". The result showed that simple social categorization was the only element required to create ingroup favoritism. ${ }^{24}$ Moreover, in our tendency to group people together we tend to exaggerate the difference between groups as well as similarities within a group. ${ }^{25}$
The idea, first properly formalized by Leon Festinger, ${ }^{26}$ that people understand who they are by reference to others - that is, through social comparison - has become a significant component in the SIT paradigm. ${ }^{27}$ Within SIT, however, it is primarily used for comparisons of in-groups and out-groups. ${ }^{28}$

In the study, the informants' perception of the Christian in-group and Hindu out-group are discussed, as well as the favoritism/prejudice associated with the two groups. Thereafter, the informants' understandings are analyzed and compared with their interaction patterns with members of the Hindu out-group and their experience of Hindu-Christian relations.

\section{Negotiating Social Identities}

The informants' perception of the two social groups "Christians" and "Hindus" diverged from a basic SIT model in several respects. Although the informants identified themselves as part of a Christian in-group and acknowledged the existence of a Hindu outgroup, they tended to point to the differences within these two groups rather than exaggerate the similarities. Therefore, both the Christian in-group and the Hindu out-group were fragmented into sub-groups. This perception of Hindus and Christians mitigated a onedimensional in-group favoritism and out-group negative stereotyping. Moreover, this also meant that the informants' perception of Hindu-Christian relations in their everyday life did not simply involve two different religious groups relating to each other, but an interaction between various Christian and Hindu sub-groups.

Despite the tendency to differentiate the Christian in-group and the Hindu out-group, the informants did express some generalized 
opinions and understandings of the two social groups. In particular, a clear distinction was made between those belonging to the Christian in-group and those who did not (namely nonChristians). This rigid division between "us and them" is a common characteristic among Pentecostals in India, ${ }^{29}$ as well as globally. ${ }^{30}$ There has been a tendency among Pentecostal groups to perceive "the world" as potentially threatening to a Christian lifestyle and, as a result, a clear division between Christians and non-Christians has been set up. However, research has shown that the understanding of the world as a threatening place has been downplayed in various places across the globe and replaced by a perception of it as a space that should and can be transformed..$^{31}$ Despite the informants' clear division between Christians and non-Christians, their perceptions of the world were more in line with this latter view. They seldom talk about nonChristian space as space that should be avoided. In contrast, several of the informants highlighted that it is important that Christians do not isolate themselves but live as Christian examples among non-Christians.

The informants' in-group favoritism was mainly displayed in two forms. First, there was a strong understanding that Christians in general are more caring than non-Christians. The social work Indian Christians are involved in and their efforts to "save souls" were highlighted as signs of Christian' unselfishness and compassion for others. Moreover, the informants with Hindu backgrounds emphasized that becoming Christian resulted in an increasing concern for people around them. As Sanjay described his conversion, "When I became Christian my total behavior got changed, you know. Before I was not taking care of anyone, when I became a Christian, I [began to] think about my neighbors." Second, several informants stressed that Christians have attained extraordinary knowledge about the world and God, to which non-Christians do not have access. For example Neeraj argued that "Christians are different, [because] they follow reality, that's why I follow Christianity. christianity is reality."

However, this in-group favoritism did not mean that all Christians were regarded as caring or enlightened. Several informants emphasized that there are Christians who are selfish and have not obtained "true knowledge of God". Moreover, strong in-group criticism was put forward by several informants. Ravi experienced that churches in his hometown were corrupt and cared more about money than being "focused on the spiritual," and shankar expressed a strong disappointment with churches in his home-village, which he believed did not teach their members proper Christian ethics and theology. Accordingly, the informants did not express one-sided favoritism as regards the Christian in-group.

The Christian in-group was primarily divided into micro-groups by appealing to the behavior of Christians. Three major types of Christians are found in the interview material: Christians "living like Hindus" (most commonly "village-Christians" and Catholics), Christians who know Jesus but do not live in accordance with the Bible, and Christians that had personally encountered Jesus and followed him in their actions. All the informants essentially identified themselves with the latter group, to which they also showed clear in-group favoritism. This group was described in very positive terms and it was repeatedly emphasized that a Christian should have a 
46 Julia Kuhlin

personal relationship with Jesus, as well as strive to "follow the Bible" as much as possible.

Denominations were only used to differentiate between different types of Christians to a minor extent. A few informants drew attention to various denominations-such as Catholics, Baptists and Methodists-but did not seem to regard denominational belonging and loyalty as important. Only three of the nine informants categorized themselves as Pentecostals. The other informants did not identify with any denomination but preferred to simply call themselves Christians. ${ }^{32}$ The latter group argued that being a Christian was not about following a certain denomination but rather following Christ. Furthermore, a couple of informants expressed that they thought that denominational labels cause more troubles than they solve.

Lukose $^{33}$ highlights how the definition of Pentecostalism causes tensions among churches in Rajasthan. There are those arguing for a broad and inclusive definition, while others are not comfortable, including the large and diverse number of independent Pentecostal churches. However, the problem of definition is not limited to intra-church contexts; it also affects researchers, who have difficulties in finding a satisfying definition of Pentecostalism. As Charismatic expressions are growing increasingly widespread among Indian Catholic churches and mainline Protestant churches, and Pentecostal-like churches are increasing, the problem of definition is likely to be a major topic of future discussion within Indian Pentecostal research.

In terms of the Hindu out-group, the informants portrayed it as an out-group, but not in a hostile or intimidating manner. Unambiguously negative statements of Hindus in general were rare. Even when the informants retold stories of how they had been badly treated by Hindus, they were careful to stress that most Hindus do not act in this way. Some informants referred to Hindus as "brothers." For example, Ajay said that Christians do not want to think negatively about Hindus, because "we have to save our brothers."

Pentecostals have been described as fostering a culture "against culture" and a community that tends to demonize other religions. ${ }^{34}$ However, this tendency was not found among the informants with regard to their attitudes towards the Hindu out-group. Lukose $^{35}$ and Suneson ${ }^{36}$ have argued that Pentecostals in contemporary India are adjusting their language and behavior towards Hindus in order not to offend anyone, in a situation where religious intolerance towards Christians is an increasing phenomenon. Even if this conclusion cannot be drawn from the material in this study, there was a strong awareness among the informants that Christians' ways of speaking and behaving towards Hindus affected Hindu-Christian relations.

While there were few negative statements of the Hindu out-group as a whole, the informants did, however, have notably different perceptions and opinions about various groups within the Hindu out-groups. The majority of Hindus were regarded as "normal Hindus": people who lived according to their tradition without much reflection and practiced their religion as it had been performed for generations. Several informants stated that the "normal Hindu" usually accepted Jesus as a god and did not mind the presence of churches, as long as Christians kept to themselves. There was, however, a prejudice among the 
informants that the Hindu acceptance of Jesus as a god was a result of their lack of knowledge about his/her own religion. For example, Renu made the following comment about Hindus' attitudes towards Jesus: "normal Hindus, they will accept him, because they don't know many things even about their own religion. So they will accept him as [a] god."

The informants did not regard themselves as being in tension with "normal Hindus," but rather perceived them as potential converts, a group that could be transformed and integrated to the Christian in-group. There was something like an evangelistic optimism present among the informants in the view that the majority of Hindus could be transformed. Therefore, rather than perceiving "normal Hindus" as a group to be avoided, there was an eagerness to reach out to this group and create good relations, which in turn could lead to opportunities to share the gospel. Accordingly, rather than perceiving "normal Hindus" as a competing out-group, they were regarded as potential members of the Christian in-group.

In contrast, "Hindu leaders" and "strongly religious Hindus" were regarded with suspicion and the informants expressed openly negative attitudes towards this category of Hindus. Some informants described them as a competing group in the endeavor to gain converts. However, while Christians' efforts to reach out with the gospel were described as an act of compassion, Hindu attempts at conversion were portrayed as a way of increasing their power and gaining more money. Normally Brahmins do receive gifts for performing rituals, but the informants had a very negative and stereotypical perception of this system. All informants argued that they were influencing the "normal Hindus" in a negative way, by, for example, spreading negative attitudes regarding Christians. It is striking that the informants were most affirmative about strongly committed members of their in-group but most critical about this within the Hindu out-group.

The informants did not directly connect Hindu nationalistic groups with the Hindu outgroup; accordingly these groups' actions and attitudes were not regarded as correlating with the Hindu out-group as such. Instead, they were described as "Hindu-biased people." The attitudes towards Hindu nationalistic groups varied. Several of the informants expressed fear and concern about their rising influence in Indian society, though a few had Christian friends who were BJP members and did not see a direct conflict between a Christian identity and a membership of a Hindu nationalistic group. The informants were well aware of the anti-Christian discourse circulating among Hindu nationalistic groups, and several informants considered that the goal of such groups was to create a Hindu India. In contrast to Hindu leaders and strongly religious Hindus, however, Hindu nationalistic groups were not regarded as a competing group but rather a part of society one feared somewhat but had to live with and adjust to.

Overall, it was clear that the informants' identification with the Christian in-group did not lead to their seeing themselves as totally differentiated from the Hindu out-group. For example, an informant from a high-caste background clearly regarded his caste identity as overlapping the Christian in-group and Hindu out-group. Similarly, another informant expressed a strong affiliation with his village, which he consequently referred to as "my people". The village was Hindu-dominated but 
48 Julia Kuhlin

included Christian, Muslim, as well as Buddhist minorities. However, the most common way in which the Christian in-group and Hindu outgroup overlapped was through families and relatives. Seven out of nine informants had Hindu family members or close relatives and were thus part of a potentially strong ingroup-the family-that consisted of both Hindus and Christians. Moreover, eight out of nine informants had close Hindu friends.

\section{Interaction patterns}

There are three main findings in terms of the informants' interaction with the Hindu outgroup. First, the informants did not show any indication of trying to avoid everyday contact with members of the Hindu out-group. Pentecostals are often described as an exclusive religious group due to their understanding of salvation, their tendency to embrace a strict moral code, etc. However, in this case study this form of exclusiveness did not imply that the informants restricted themselves to only interacting with their religious in-group. All informants had family members, relatives or close friends that were Hindus, with whom they frequently intermingled. Consequently, the informants had close relations with members of the Hindu out-group that bridged the two religious groups in everyday life. It is likely that the informants' everyday interaction with members of the Hindu out-group contributed to a more nuanced perception of the out-group and may be the reason why negative stereotyping of the Hindu out-group as a whole was rare among the informants.

The informants' association with multireligious-groups (such as their family or village) implied that there were times when they had to negotiate their own religious identity. A frequently-cited example of this was Hindu festivals which offered two major dilemmas: (1) to what extent can one participate in Hindu festivals, and (2) to what extent can one financially contribute to Hindu festivals? The second dilemma was the foremost concern of informants from rural areas, as it is customary in many villages that every family financially contributes to the larger (Hindu) festivals. Even if the informants held ambivalent feelings regarding contributing financially to Hindu festivals, all informants' families living in villages did give money. These informants, however, argued that if you live in a village you have to follow the system, e.g., "because we live in a village, we need to give. We ask for something, and we give something. It is like that." The other dilemma, concerning participation in Hindu festivals, troubled all informants; they were in agreement that it was a sensitive matter for both themselves and their Hindu family and friends. The degree of participation varied between informants, but all expressed a desire not to offend their Hindu family members and friends while nonetheless remaining true to their own religious identity.

The second main finding concerning interaction patterns is that there was a significant difference in the ways that informants from urban and rural areas interacted with the Hindu out-group. The informants living in villages described village life as being part of a multi-religious community, which worked together and helped each other in day-to-day life. As a result, these informants did not only intermingle with Hindu friends or family members, but also had a significant amount of daily contact with other members of the Hindu out-group. Moreover, 
social religious identity was much more prominent in villages, which implied a vulnerable situation for Christians living as a minority. The informants who lived in villages emphasized that Christians needed to adjust their behavior due to the unequal powerrelations between Christians and the Hindu majority.

However, interaction patterns varied as a result of the specific circumstances that prevailed in each particular village. For example, one informant had left the village he grew up in several years ago, since neither his high caste family nor the rest of the village accepted his conversion to Christianity (which they perceived as a low-caste religion). In another informant's village, Christians and Hindus intermingled to the extent that interreligious marriage was not unusual.

For the informants living in cities, solidreligious identity seemed to play only a minor role in the interaction with people they did not personally know. These informants did not describe random interactions with colleagues, rickshaw drivers, or shopkeepers as interacting with "Hindus." Moreover, the informants living in cities were not part of larger multi-religious communities that brought Christians and Hindus together and thus interacted with the Hindu out-group to a lesser extent.

Despite this difference in interaction patterns between informants from urban and rural areas, they did not have notable different perceptions of the Hindu out-group. In other words, additional contact (beyond family and friends) with Hindus did not seem to affect the informants' perception of the Hindu out-group. On the other hand, the informants living in rural areas emphasized the importance of respecting the norm of the majority to a larger extent.

The third main finding concerning the informants' interaction patterns with the Hindu out-group is that, even if it was evident that the informants regarded evangelism as vital-as Pentecostals tend to do-it was not a primary way in which they interacted with Hindus. Moreover, the majority of the informants held the opinion that the gospel should be shared within already-existing relationships-and were thus critical of street evangelism. The optimistic attitude that "normal Hindus" were potential Christians was downplayed as the informants described the difficulties in talking about the gospel with Hindus. They knew from experience that the idea that the Christian God is the only true one was offensive to Hindus and, therefore, instead hoped that their actions would show the way to Christ. Evangelistic efforts primarily occurred among family and friends.

Three informants were or had been involved in evangelism directed towards strangers: one in street evangelism and two in team evangelism in villages with their churches. These informants described how they were often met with suspicion, anger and on infrequent occasions, violent acts. Despite this, they had a fairly positive attitude towards "street- and village evangelism." Bauman describes in his recent book on Pentecostals and anti-Christian violence that he encountered churches where violence in connection with evangelization is glorified rather than problematized through reference to biblical passages about the righteous being persecuted. ${ }^{37}$ In one informant's church this attitude seemed to be present. When asked if he wasn't afraid of what might happen when he 
and his church travelled to unfamiliar villages for evangelism, he responded that his pastors had taught him: "[there is] no need to be afraid of people. They are just persecuting and we are preaching. Just let them do their job and let us do our job." As Bauman argues, this type of fatalistic attitude towards Hindu-Christian relations is highly problematic and may contribute towards worsening relations.

\section{Experiences of Hindu-Christian Relations}

The informants described their experience of the relationship between the Christian ingroup and the Hindu out-group differently on micro, meso, and macro levels. Close relationships with members of the Hindu outgroup (family, relatives and friends) were portrayed as predominately well-functioning. However, there was a difference between how the relationship with Hindu friends was experienced in comparison with Hindu family members. Belonging to different religions seemed to play a minor role in friendship, but did, at times, cause conflicts and disputes within families. Those informants who had converted described how this had initially given rise to strong reactions within their family. However, all families-except one-had now accepted their conversion. Nonetheless, even if the families had accepted their conversion, discussions and, to some extent disputes, over religious matters were not unusual.

Several informants stressed that they experienced an unequal power-relation between Hindus and Christians in their hometowns/villages; that it was noticeable that Christians lived in a minority situation. In one informant's city, Christians lived together in colonies for the purpose of safety. Eight out of nine informants had themselves, or knew somebody, who had experienced some sort of physical harassment due to being Christians. In spite of such incidents, the informants generally experienced that the Christian ingroup and Hindu out-group were getting along in their hometowns/villages. Tensions, conflicts and incidents of harassment of Christians were regarded as exceptions to the general state of peaceful coexistence. The conflicts that occurred on these levels were understood as exceptions to a largely troublefree coexistence, and were often explained by the recollection that the persons causing conflict were Hindu leaders or strongly religious Hindus who didn't like Christians. Therefore, the informants did not experience Hindu-Christian relations in their nearest surroundings to be in a critical state.

The informants did however experience that there existed a great deal of prejudice towards Christians within their Hindu surroundings. They often encountered prejudice from Hindus that Christians were immoral, were supported by foreigners and were of a low caste religion. The most common negative preconception the informants encountered from Hindus was that Christianity, as a "foreign religion," does not belong in India. According to the informants, this common Hindu nationalist standpoint is widespread among the Hindu population.

When the informants talked about their more general experiences of Hindu-Christian relations in India, they expressed distress and seemed worried. Several informants mentioned the Kandhamal Riots in Orissa 2007-2008 ${ }^{38}$ and the burning of the missionary Graham Staines and his two sons. The riots were evidence for the informants that Hindu-Christian relations 
were, in fact, unstable. The informants living in cities, in particular, stressed Hindu-Christian relations in rural areas as being tense. Moreover, the majority of the informants experienced that politicians were "Hindu biased" and did not properly protect or care for the Christian minority. The informants also expressed fear of the effects of the BJP winning the national elections and Narendra Modi becoming prime minister. Eight out of nine informants believed that it would have a negative impact on Hindu-Christian relations.

Accordingly, while the relationship between the Christian in-group and the Hindu out-group on a national level was described as worrying and unstable, the experienced relationship on the micro- and meso-levels was described as largely conflict-free. This discrepancy may be due to media coverage, what the informants have read online, what is said in churches etc. In the informants' description of their encounters with Hindus on the micro- and meso levels, they presuppose that the majority of Hindus are what they called "normal Hindus"-to whom they had a quite positive attitude. However, when distancing themselves from their local context, this understanding of the Hindu out-group seemed to be forgotten and was replaced by an understanding that diverged from their everyday experiences.

\section{Conclusion}

The aim of this study was to better understand Hindu-Christian relations in the everyday lives of north Indian Pentecostals. The article has focused on (1) the perception of the two social groups "Christians" and "Hindus", (2) how the informants' experience Hindu-Christian relations, and (3) how they interact with the Hindu out-group.
The informants perceived the social groups "Christians" and "Hindus" as internally divided. Consequently, Hindu-Christian relations involved various sub-groups within both the Christian in-group and the Hindu out-group relating to each other (e.g. "strong Christians" with "normal Hindus", or "Christians living like Hindus" with "Hindu religious leaders"). The majority of Hindus-the "normal Hindus"were perceived as potentially Christian rather than as a competing out-group. In contrast, Hindu leaders and "strongly religious Hindus" were regarded with suspicion and portrayed as a rival out-group by several informants.

By focusing on the informants' everyday interaction patterns with the Hindu out-group, the study has problematized the common assumption that Pentecostals are an exclusive and predominately insular religious group. In addition to interacting with Hindu family members and relatives, eight out of nine informants had close Hindu friends with whom they regularly intermingled. Moreover, it was regarded as positive to have close relationships with members of the Hindu out-group, since it provided a starting-point for a sharing the gospel. Further, there was a notable difference in how the informants described their experiences of Hindu-Christian relations on micro- and meso-levels compared to a macro one. Within close relationships, as well as in their home-towns/villages, conflicts between Christians and Hindus were regarded as exceptions to a more or less peaceful coexistence. In contrast, fear and anxieties characterized their description of HinduChristian relations on a national level.

In order to get a more nuanced portrayal and in-depth understanding of the everyday lives of Pentecostals and their relation to the 
Hindu majority, further and more extensive ethnographic studies are needed. Considering the contemporary situation, where violence against Christians-particularly Pentecostals and Pentecostal-like groups-has risen significantly, further investigation of the situation and lives of Pentecostals is perhaps of even vital concern.

\section{Notes}

${ }^{1}$ Chad Bauman \& Tamara Leech, "Political Competition, Relative Deprivation, and Perceived Threat: a Research Note on AntiChristian Violence in India," Ethnical and Racial Studies 53, no. 12 (2012): 2213.

${ }^{2}$ Doon Bible College started as a short term Bible course by Harry Liddle in 1943 in Agra. In 1945 Liddle moved to Dehradun were he continued his work and extended the education to a two-year long training program called Maranata Bible School. As the school started to received more and more applications from different Indian linguistic regions in the early 1950s, the language of instruction changed to English, and the school was renamed Doon Bible School (DBC). Since its inception DBC has had close connections with the Swedish Pentecostals movement, relations which have continued to the present day. Today the college is open for both men and women and enrolls between 60-70 students each year. The highest academic program offered at present is a Bachelor in Theology. See Barbro Andreasson, Eric Andreasson \& Billy Johansson, Svensk Pingstmission $i$ Indien (Huddinge: MissionsInstitutet-PMU, 2000).

${ }^{3}$ For example: the revival in Tirunelveli in 1860, several indigenous revivals in Kerala during the period of 1873-1908, and the revival at the girls' school in Sialkot in 1904. These revivals were all characterized by Spirit manifestation, such as speaking in tongues, prophecy, visions, bodily shaking and falling down (Wessly Lukose, Contextual Missiology of the Spirit: Pentecostalism in Rajasthan, India (Eugene, Oregon: Wipf \& Stock, 2013), 36-44; Yabbeju Rapaka, Dalit Pentecostalism: a Study of the Indian Pentecostal Chruch of God, 1932 to 2010 (USA: Emeth Press, 2013), 23-34.

${ }^{4}$ Arun W. Jones, "Faces of Pentecostalism in North India Today" Society 46, no. 6. (2009):504509

${ }^{5}$ Michael Bergunder, The South Indian Pentecostal Movement in the Twentieth Century. (Grand Rapids, MI: Eerdmans Publishers, 2008), 23-36

${ }^{6}$ This especially applies to the Pentecostal movement in North India. In contrast to South India, where a strong Christian presence has existed for centuries, the movement in North India constantly found itself in Hindu dominant-surroundings. As a result, the Pentecostal movement in North India has to, a greater extent. focused on establishing orphanages, schools, leper asylums, etc. See Stanley Burgess, "Pentecostalism in India: an Overview," Asian Journal of Pentecostal Studies 4, no. 1 (2001): 91-94

${ }^{7}$ Chad Bauman, Pentecostals, Proselytization and Anti-Christian Violence in Contemporary India. (New York: Oxford University Press, 2015), 27.

8 Bergunder, The South Indian Pentecostal Movement in the Twentieth Century, 136, 191-208.

${ }^{9}$ See e.g. Bergunder, The South Indian Pentecostal Movement in the Twentieth Century; Bauman, Pentecostals, Proselytization and Anti-Christian Violence in Contemporary India; Lukose, Contextual Missiology of the Spirit. 
10 Sebastian Kim, In Search for Identity (New Delhi: Oxford University Press, 2003).

${ }^{11}$ Ibid. 37-58.

${ }^{12}$ Bauman, Pentecostals, Proselytization and AntiChristian Violence in Contemporary India, 173-193.

${ }^{13}$ Ibid. 78-83.

14 Bergunder, The South Indian Pentecostal Movement in the Twentieth Century, 123-129.

${ }^{15}$ Bauman, Pentecostal, Proselytization, and AntiChristian Violence in Contemporary India, 94-130

16 Joel Robbins, "The Globalization of Pentecostal and Charismatic Christianity," Annual Review of Anthropology 33, no. 1 (2004): 127-130.

${ }^{17}$ Anita Suneson "'"Everybody His Own People" Pentecostalism and Religious Plurality in Bangalore," Swedish Missiological Themes 96, no 3 (2008): 272-274

${ }^{18}$ Lukose, Contextual Missiology of the Spirit, 85-86. 19 Research for this study was originally undertaken for a Master's thesis, which is the reason for the small size of the sample. For a full version of the thesis see Julia Kuhlin Love Thy Hindu Neighbor as Thyself: A Field Study of North Indian Pentecostals' Perceptions of HinduChristian Relations. Lund University, Centre for Theology and Religious Studies (2014).

${ }^{20}$ Jens Rennstram \& David Wästerfors "Att analysera kvalitativt material," in Handbok för kvalitativ metoder, eds. Göran Ahrne \& Peter Svensson (Malmö: Liber, 2012): 194-209.

${ }^{21}$ Michael A. Hoog, Deborah J. Terry \&Katharine M. White, "A Tale of Two Theories: A Critical Comparision of Identity Theory and Social Identity Theory," Social Psychology Quarterly 58, no.4 (1995): 259.

${ }^{22}$ Karina V. Korostelina Social Identity and Conflict (New York: Palgrave Macmillan, 2007), 23.
23 Henri Tajfel Social Identity and Intergroup Relations (London: Cambridge University, 1981), 255.

${ }^{24}$ It had earlier been assumed that group bias, both in-group favoritism and out-group prejudice, derived from cooperative dependence among group members. Tajfel and his colleagues challenged this theory and proposed that affiliation was not necessary for in-group favoritism to emerge; social categorization was enough to create support for in-groups. See Korostelina, Social Identity and Conflict, 23-25.

${ }^{25}$ Henri Tajfel \& John Turner, "The Social Identity Theory of Intergroup Behavior," In Psychology of Intergroup Relations, eds. Stephen Worchel \& William G. Austen (Chicago: Nelson Hall, 1986): 7-24.

26 Leon Festinger, "A Theory of Social Comparison Processes," Humans Relations 7, no. 2 (1954): 117-140

27 John Turner, "Some Current Issues in Research on Social Identity and SelfCategorization Systems," in Social Identity: Context, Commitment, Content eds. Naomi Ellmers, Russell Spears \& Bertjan Doosje (Oxford: Blackwell, 1999), 8

${ }^{28}$ The motivation for comparison with others is most often explained as a desire for positive self-evaluation.

29 Bergunder, The South Indian Pentecostal Movement in the Twentieth Century.

${ }^{30}$ Robbins, The Globalization of Pentecostal and Charismatic Christianity

${ }^{31}$ See e.g. Hans G. Aasmundsen Pentecostalism, Globalisation and Society in Contemporary Argentina (Huddinge: Södertörn University, 2013); Simon Coleman \& Katrin Maier "Redeeming the City: Creating and Traversing 
54 Julia Kuhlin

'London-Lagos,' Religion 43, no. 3 (2013):353-364;

Barbara Bompani \& Terreni Brown A "Religious

Revelation? Print Media, Sexuality, and Religious Discourse in Uganda," Journal of Eastern African Studies 9, no. 1 (2014):110-126.

${ }^{32}$ Even if several of the informants did not want to categorize themselves as Pentecostals, they all showed a typical Pentecostal-like approach towards various issues, e.g. the mission, the Holy Spirit, the Bible, salvation, and can therefore, from an etic point of view, be defined as Pentecostals.

${ }^{33}$ Lukose, Contextual Missiology of the Spirit, 71.

${ }^{34}$ Robbins, The Globalization of Pentecostal and Charismatic Christianity.

${ }^{35}$ Lukose, Contextual Missiology of the Spirit, 85-86.

${ }^{36}$ Suneson, "Everybody His Own People", 272-274.

${ }^{37}$ Bauman, Pentecostals, Proselytization, and AntiChristian Violence in Contemporary India, 188-189.

${ }^{38}$ The Kandhamal Riots were triggered by a dispute over Christian Christmas decorations in Brahmanigao and a claimed attack by a group of Christians on Swamie Laxamanananda Saraswati's car on his way to the town. However, the riot exacerbated a long-standing tension between Hinduized adivasi Kandhas and Christian Dalit Panas. In the riots nearly a hundred people were killed, hundreds of homes and many Christian institutions were destroyed, and thousands of people fled from their homes. See Chad Bauman \& Richard F. Young, "Minorities and the Politics of Conversion: With Special Attention to Indian Christianity," in Minority Studies, ed. Rowena Robinson (New Delhi: Oxford University Press, 2012), 193-196. 